\title{
O ESTADO DA ARTE DA PRODUÇÃO CIENTÍFICA EM GESTÃO ESCOLAR (2010 A 2015) Solange Mary Moreira Santos ${ }^{1}$; Maísa Lis Costa Alves²; \\ 1. Professora plena do Departamento de Educação, Universidade Estadual de Feira de Santana, e-mail: solangemmsantos@gmail.com \\ 2. Bolsista PROBIC/UEFS, Graduando em Licenciatura em Pedagogia, Universidade Estadual de Feira de Santana, e-mail: maiisacliis@hotmail.com
}

PALAVRAS-CHAVE: Gestão Escolar; Gestão Democrática; Estado da Arte.

\section{INTRODUÇÃO:}

Esta investigação contribuiu para as discussões e análises sobre a gestão escolar, disponibilizadas em referenciais bibliográficos, sites eletrônicos, periódicos, eventos, teses e dissertações, a fim de ampliar o conhecimento sobre o tema e fomentar novos debates no que concerne às políticas educacionais, nas quais seguramente se faz presente a gestão escolar. O estudo em voga também propiciou reflexão diante das mais diferentes visões sobre gestão, não deixando de perceber a importância da origem dos conceitos para o entendimento e estudos dos conceitos atuais. A pesquisa realizada foi de abordagem qualitativa, do tipo descritiva, porque representa "um processo de reflexão e análise da realidade através da utilização de métodos e técnicas para a compreensão detalhada do objeto de estudo em seu contexto histórico e/ou segundo sua estruturação" (OLIVEIRA, 2007, p. 37). Nesse sentido, o entendimento é o pontuado por Oliveira, ao conceituar os métodos, tendo em vista que nesse tipo de abordagem tudo deve ser registrado, favorecendo a identificação e o estudo da complexidade dos problemas.

Assim, foi utilizado como procedimento metodológico o estado da arte da produção científica sobre gestão escolar, nos últimos cinco anos, contribuindo para a divulgação de estudos que se dedicam a refletir sobre as questões que afetam a gestão escolar. Também se utilizou a pesquisa bibliográfica, para mapear e delimitar as produções acadêmicas em diferentes campos do conhecimento, as dimensões em que a área da gestão vem se destacando em diferentes artigos, e as questões que têm afetado, nos últimos cinco anos, a gestão escolar.

Dessa forma, esta pesquisa sistematizou a produção científica em torno do tema da gestão escolar, gestão democrática e estado da arte, considerando o período entre 2010 a 2015. Optou-se então por realizar o estado da arte nos periódicos das revistas 
Associação Nacional de Pós-Graduação e Pesquisa (ANPED); Associação Nacional de Política e Administração em Educação (ANPAE).Também, o levantamento nos anais do Congresso Nacional de História da Educação e nas teses e dissertações da plataforma do banco de teses e dissertações da Coordenação de Aperfeiçoamento de Pessoal de Nível Superior (CAPES).

O alicerce teórico embasa-se e ancora-se nas produções de autores como Libâneo (2007), que se refere à gestão escolar como uma atividade coletiva; Paro (1996), ao conceber que a gestão está inserida em grupos de interesses; Cury (2006), trazendo uma reflexão sobre gestão democrática e o direito à educação; Ferreira (2008), que fortalece a discussão de gestão e novos desafios; Sousa (2006), com um levantamento teórico sobre as produções cientificas no âmbito da gestão escolar no Brasil; e Vieira (2007), com a apresentação de conceitos simples sobre políticas e gestão da educação básica, entre outros pesquisad ores da temática. Assim, diante do exposto, esta investigação teve a pretensão de responder ao seguinte questionamento: Quais concepções, características e princípios aparecem nos artigos e dissertações pesquisados entre 2010 a 2015 ?

\section{DESENVOLVIMENTO:}

$\mathrm{Na}$ análise preliminar identificou-se que, nos anos investigados (2010-2015), os artigos, teses e dissertações publicadas contemplam autores diversificados advindos de diferentes regiões do país, porém existe uma predominância da região Sul e Sudeste, evidenciando assim uma lacuna no que tange às discussões acerca do tema gestão escolar nas regiões mais pobres economicamente.

$\mathrm{Na}$ análise dos anais do Congresso Nacional de História da Educação-CNHE foi encontrado apenas 1 (um) artigo que dialogava com o objetivo desse trabalho. Assim, a concepção da gestão escolar nesse artigo é abordada a partir do contexto histórico. Nesse artigo, Oliveira (2013) se preocupa em contextualizar a historicidade da gestão escolar, visto que o objetivo principal do Congresso Nacional de História da Educação é discutir a história da educação. Nesse sentido, a autora aborda a concepção de gestão democrática, com o argumento de que uma escola precisa se respaldar em princípios que regem essa gestão, como a participação, a autonomia e a democratização.

$\mathrm{Na}$ Revista Brasileira de Política e Administração da Educação-RBPAE, foram encontrados 4 (quatro) artigos que tiveram como foco principal discutir a concepção de gestão escolar como um todo, ou seja, situando e conceituando o termo gestão. Entre os 4 (quatro) artigos encontrados nessa revista, 2 (dois) versavam sobre o estado da arte da 
gestão escolar, a partir das publicações da RBPAE e da RBAE. Entendeu-se que esse tipo de pesquisa denominada "estado da arte" é um contributo para fomentar as discussões que estão sendo vinculadas nos artigos publicados, para assim entendermos a materialização da prática na escola. Os outros 2 (dois) artigos abordam sobre os limites e possibilidades de construção de uma vivência democrática na gestão e no fazer pedagógico. Nesse sentido, compreendeu-se que os artigos da RBPAE trazem uma concepção de gestão escolar a partir de uma contextualização da gestão como um todo, aparecendo nos artigos superficialmente as características como a participação, autonomia e democratização.

Na Revista Brasileira de Educação-RBAE foram encontrados 2 (dois) artigos que discutem concepções de gestão voltadas à prática participativa e também à prática burocrática na escola. Os textos publicados apresentam estudos teórico-práticos que sinalizam a gestão como um processo político de poder. Portanto, os artigos da RBAE contêm uma concepção de gestão alicerçada na ótica da administração, já que discutem o controle sobre o poder escolar, se opondo à concepção que é abordada, seja nos artigos da CNHE, seja nos achados da RBPAE, os quais defendem uma gestão democrática para a construção de uma educação de qualidade.

$\mathrm{Na}$ plataforma CAPES de teses e dissertações foram encontradas 13 (treze) dissertações e 2 (duas) teses. Dessa forma, as pesquisas analisadas defendem uma concepção de gestão escolar democrática, sendo que o princípio da participação aparece em todas as produções publicadas. Ou seja, os autores acreditam que para se ter uma educação pública de qualidade é necessário que a gestão escolar esteja embasada em uma concepção democrática, possibilitando que a comunidade tenha acesso e manifeste seus desejos de uma escola de qualidade, para garantir o que regem os princípios constitucionais e aqueles relacionados à gestão escolar: a democratização do ensino e a autonomia da escola.

Diante dos dados coletados e das reflexões realizadas, as publicações do CNHE e da RBPAE situam os leitores no que se refere às abordagens já realizadas acerca da gestão escolar e da sua concepção no entendimento geral. Já as publicações da RBAE se voltam para uma concepção mais antiga, da burocratização da gestão. Quanto às produções da plataforma CAPES, estas pontuam a democratização da escola na perspectiva da qualidade do ensino.

\section{CONCLUSÃO:}


Os resultados desta pesquisa possibilitaram perceber que a concepção de gestão democrática integra a maioria dos textos aqui discutidos, tanto dos artigos quanto das teses e dissertações. Dessa forma, emerge a compreensão de que o campo de pesquisa em gestão escolar no Brasil ainda se encontra em processos de construção, porquanto será preciso superar alguns desafios, para atingir o tão propagado modelo democrático e participativo de organização da escola. Desse modo, os estudos revelam que existe uma grande lacuna entre a teoria e a prática, apesar de existirem excelentes trabalhos na área de gestão escolar que defendem uma concepção gestão democrática, com características e princípios como a participação, autonomia e democratização. Os dados ainda evidenciam que no Nordeste há pouca produtividade na área de gestão escolar, principalmente na Bahia, abrindo assim campo de estudo para outras produções acerca da gestão escolar.

O trabalho ora apresentado é, portanto, de grande relevância para a área da educação, pois proporciona reflexões importantes para ampliar conhecimentos sobre a área da gestão escolar, como também explora os conhecimentos dessa temática, tanto para os que pretendem atuar na área de gestão quanto para os que visam à docência, uma vez que essas questões fazem parte de todo o processo educativo. Nesse sentido, acredita-se que o trabalho ajudou a contribuir para elevar a compreensão sobre o tema, além de proporcionar a aquisição de conhecimentos que norteiam as discussões, em nível nacional, relacionadas à gestão escolar.

\section{REFERÊNCIAS}

CURY, Carlos Roberto Jamil. A educação básica como direito. Cadernos de Pesquisa, v. 38, n. 134, maio/ago. 2008.

LIBÂNEO, José Carlos; OLIVEIRA, João Ferreira de; TOSCHI, Mirza Seabra (Orgs.). Educação escolar: políticas, estrutura e organização. 10. ed. rev. e ampl. São Paulo: Cortez, 2012. (Coleção docência em formação: saberes pedagógicos).

OLIVEIRA, Maria Marly de. Como fazer uma pesquisa qualitativa. Petrópolis, RJ: Vozes, 2007.

PARO, Vitor Henrique. Administração escolar: introdução crítica. 17. ed. revista e ampliada. São Paulo: Cortez, 2012. 